\title{
PELAKSANAAN FUNGSI APARAT PENGAWAS INTERN PEMERINTAH (APIP) UNTUK MENUNJANG TINGKAT KEWAJARAN LAPORAN KEUANGAN PEMERINTAH KOTA MANADO
}

\author{
Merry Inggrid Siwy \\ David P.E. Saerang \\ Herman Karamoy \\ Email : merry_1nggr1d@yahoo.com
}

\begin{abstract}
Internal Audit is the whole process of audit activities, the Review, evaluation, monitoring and supervisory activities other against the implementation of tasks and functions of the organization in order to provide reasonable assurance that the activities have been carried out in accordance with the benchmarks that have been set effectively and efficiently for the benefit of the leadership to Realize good governance.

Accountability and transparency in the new government could be achieved if all levels of leadership controlling activities on the overall activities in their respective agencies. Internal control system (SPI) is a process that is integral to the actions and activities carried out continuously by the management and all employees to provide reasonable assurance on the achievement of organizational goals through effective and efficient, the reliability of financial reporting, the safeguarding of state assets, and compliance with legislation. To strengthen and support the effectiveness of internal control over the SPI made implementation of tasks and functions of government agencies including state audits carried out by the internal control official Government ( APIP).

The auditor's responsibility to detect fraud or irregularity embodied in the planning and execution to obtain reasonable assurance about whether the financial statements have been prepared in accordance with established standards.

The purpose of this study was to analyze the functions of Government Internal Supervisory Apparatus (APIP) / Internal Auditor in supporting reasonable levels of Local Government Finance Report Manado City. Respondents were selected are few skilled examiner at the office of the Inspectorate of Manado. Approach Using Qualitative methods Ethnography.

APIP functions that work well to prevent fraud, to produce valuable output to be input to the external auditor, the executive and the legislature to improve financial management and accountability in the area of the future . Eksternal Auditor may use the results from the monitoring APIP mainly reviews the financial statements of the government, supporting the management of local government in implementing the recommendations and improvements Internal control system. APIP professional and independent encourage increased transparency and accountability in financial management to improve the fairness of the financial statements .
\end{abstract}

Keywords: Government Internal Supervisory Apparatus, fraud detection, the fairness of the financial statements.

\subsection{Latar Belakang Masalah}

\section{PENDAHULUAN}

Semakin meningkatnya tuntutan masyarakat atas penyelenggaraan pemerintahan yang bersih, adil, transparan, dan akuntabel harus disikapi dengan serius dan sistematis. Segenap jajaran penyelenggara negara, baik dalam tatanan eksekutif, legislatif, dan yudikatif harus memiliki komitmen bersama untuk menegakkan good governance dan clean government. Seiring dengan hal tersebut, pemerintah pusat dan daerah telah menetapkan sasaran untuk meningkatkan pelayanan birokrasi kepada masyarakat dengan arah kebijakan penciptaan tata pemerintahan Yang bersih dan berwibawa (good governance). Dengan adanya komitmen pemerintah untuk mewujudkan good governance maka kinerja atas penyelenggaraan organisasi pemerintah menjadi perhatian pemerintah untuk dibenahi, salah satunya melalui sistem pengawasan yang efektif, dengan meningkatkan peran dan fungsi dari Aparat Pengawas Intern Pemerintah (APIP). Pengawasan intern adalah seluruh proses kegiatan audit, reviu, evaluasi, pemantauan, dan kegiatan pengawasan lain terhadap penyelenggaraan tugas dan fungsi organisasi dalam rangka memberikan keyakinan yang memadai bahwa kegiatan telah dilaksanakan sesuai dengan tolok ukur yang telah ditetapkan secara efektif dan efisien untuk kepentingan pimpinan dalam Mewujudkan tata kepemerintahan yang baik.

Salah satu faktor utama yang dapat menunjang keberhasilan pelaksanaan pengendalian Intern adalah efektivitas peran Aparat Pengawasan Intern Pemerintah (APIP). Untuk itu, APIP harus terus melakukan perubahan dalam menjalankan proses bisnis guna memberi nilai tambah bagi kementerian negara/lembaga dan penyelenggaraan pemerintahan daerah. Hal ini sejalan dengan peran pengawasan intern untuk mendorong peningkatan efektivitas manajemen risiko (risk management), pengendalian (control) dan tata kelola (governance) organisasi. APIP juga mempunyai tugas untuk melakukan pembinaan Sistem Pengendalian Intern Pemerintah (SPIP) sebagaimana diamanatkan dalam Peraturan Pemerintah Nomor 60 Tahun 2008 tentang Sistem Pengendalian Intern Pemerintah.Peran Inspektorat Daerah sebagai Aparat Pengawasan Internal Pemerintah( APIP ), Inspektorat Daerah memiliki peran dan posisi yang sangat strategis baik ditinjau dari aspek fungsi-fungsi manajemen maupun dari segi pencapaian visi dan 
misi serta program-program pemerintah. Dari segi fungsi-fungsi dasar manajemen, ia mempunyai kedudukan yang setara dengan fungsi perencanaan atau fungsi pelaksanaan. Sedangkan dari segi pencapaian visi, misi dan programprogram pemerintah, Inspektorat Daerah menjadi pilar yang bertugas sebagai pengawas sekaligus pengawal dalam pelaksanaan program yang tertuang dalam Anggaran Pendapatan dan Belanja Daerah.

\subsection{Rumusan Masalah}

Berdasarkan uraian diatas yang dikemukakan pada latar belakang masalah, maka masalah pokok dalam penelitian ini adalah "Bagaimana Internal Auditor menjalankan fungsi sehingga dapat menemukan / mendeteksi kecurangan yang dapat mempengaruhi tingkat kewajaran Laporan Keuangan"

\subsection{Tujuan Penelitian}

Tujuan dalam penelitian ini adalah “ Untuk menganalisis fungsi APIP / Internal Auditor dalam menunjang tingkat kewajaran Laporan Keuangan Pemerintah Daerah (LKPD)”

\subsection{Manfaat Penelitian}

Manfaat yang diharapkan dari penelitian ini adalah :

1. Bagi auditor internal penelitian ini diharapkan dapat memberikan manfaat sebagai bahan acuan dan pertimbangan didalam proses pelaksanaan pemeriksaan.

2. Bagi Pemerintah penelitian ini diharapkan dapat memberikan gambaran kelemahan sistem pengendalian di Instansi Pemerintahan, sehingga Pemerintah dapat memperbaiki pengendalian internal di lingkungan pemerintahan dan membuat regulasi untuk memperkuat struktur keuangan di pemerintahan.

3. Bagi masyarakat penelitian ini diharapkan sebagai gambaran modus kecurangan yang terjadi di lingkungan masyarakat dan pendeteksiannya, sehingga masyarakat juga peka terhadap tindak kecurangan di sekitarnya.

\subsection{Landasan Teori}

\section{TINJAUAN PUSTAKA}

\subsubsection{Teori keagenan}

Dalam teori keagenan yang dikemukakan oleh (Suwardjono, 2011, 485), dinyatakan bahwa hubungan keagenan adalah hubungan antara principal dan agen yang didalamnya agen bertindak atas nama dan untuk kepentingan principal dan atas tindakannya tersebut agen mendapatkan imbalan tertentu. Hubungan tersebut biasanya dinyatakan dalam kontrak. Dalam teori keagenan, agen biasanya dianggap sebagai pihak yang ingin memaksimumkan dirinya tetapi agen tetap selalu berusaha memenuhi kontrak.

Eisenhardt $(1989,3)$ menjelaskan bahwa agency theory is concerned with resolving two problems that can occur in agency relationships. The first is the agency problem that arises when (a) the desires or goals of the principal and agent conflict and (b) it is difficult or expensive for the principal to verify what the agent is actually doing. The second is the problem of risk sharing that arises when the principal and agent have different attitudes toward risk. The problem here is that the principal and the agent may prefer different actions because of the different actions because of different risk preference.

Eisendhart menjelaskan bahwa agency teori berfokus kepada penyelesaian masalah pada hubungan keagenan yaitu perbedaan tujuan antara principal dan agen serta biaya yang cukup tinggi untuk melakukan pengawasan kepada agen. Permasalahan lain yaitu masalah pembagian resiko dimana principal dan agen akan memiliki perbedaan aksi yang disebabkan tingkat perbedaan toleransi resiko.

Audit quality forum $(2005,6)$ menjelaskan bahwa Perbedaan motivasi dan informasi yang asimetri menyebabkan kekhawatiran tentang keandalan informasi yang diberikan, yang berdampak pada tingkat kepercayaan principal kepada agen mereka. Ada berbagai mekanisme yang dapat digunakan untuk mencoba menyelaraskan kepentingan agen dengan principal sehingga memungkinkan principal untuk mengukur dan mengontrol perilaku agen mereka dan memperkuat kepercayaan agen. Paket remunerasi dan insentif bagi agen dapat memberikan suatu mekanisme yang efektif, seperti dalam mekanisme pasar atas kontrol perusahaan berupa perekrutan dan pemecatan dewan direksi. Mekanisme seperti itu, bagaimanapun, membuat potensi masalah baru yang berkaitan dengan pengukuran kinerja. Tugas agen dapat ditulis ke dalam kontrak dan membuat penegakan atas subjek dan denda atau alternatif adalah untuk mewujudkan tugas agen dalam perjanjian, seperti tugas ditempatkan kepada direksi di bawah hukum perusahaan. Mekanisme monitoring lain adalah audit. Audit memberikan pemeriksaan independen atas pekerjaan agen dan informasi disediakan oleh agen, yang membantu untuk menjaga kepercayaan dari principal.

\subsubsection{Karakteristik Laporan Keuangan}

A. Pengertian Karakteristik

Secara etimologis istilah karakteristik tafsir merupakan susunan dua kata yang terdiri dari kata; karakteristik dan tafsir. Istilah karakteristik diambil dari bahasa Inggris yakni characteristic, yang artinya mengandung sifat khas. Ia mengungkapkan sifat-sifat yang khas dari sesuatu.

B. Pengertian Laporan Keuangan

Laporan keuangan adalah catatan informasi suatu entitas pada suatu periode akuntansi yang dapat digunakan untuk menggambarkan kinerja entitas tersebut. Laporan keuangan merupakan laporan yang terstruktur mengenai posisi keuangan dan transaksi-transaksi yang dilakukan oleh suatu entitas pelaporan. Tujuan laporan keuangan pemerintah adalah untuk menyajikan informasi yang berguna untuk pengambilan keputusan serta untuk menunjukkan akuntabilitas 
entitas pelaporan atas sumber daya yang dipercayakan kepada pemerintah. Pelaporan keuangan juga menyajikan informasi bagi pengguna mengenai:

1. Indikasi apakah sumber daya telah diperoleh dan digunakan sesuai dengan anggaran.

2. Indikasi apakah sumber daya diperoleh dan digunakan sesuai dengan ketentuan, termasuk batas anggaran yang ditetapkan oleh DPR/DPRD.

C. Tujuan Laporan Keuangan

Tujuan pelaporan keuangan adalah untuk menyediakan informasi yang bermanfaat untuk mengevaluasi kinerja manajerial dan organisasional. Pelaporan keuangan membantu memenuhi kewajiban pemerintah untuk menjadi akuntabel secara publik. Untuk tujuan tersebut, pelaporan keuangan harus mempertimbangkan kebutuhan para pengguna dan keputusan yang mereka buat. Oleh karena itu laporan keuangan PEMDA harus memenuhi kebutuhan pengguna yang menginginkan transparansi dan akuntabilitas atas pengelolaan keuangan publik untuk berbagai kepentingan pengguna salah satunya penggunaan informasi laporan keuangan sebagai dasar pengambilan keputusan. Informasi yang disajikan dalam laporan keuangan pemerintah baik pusat dan daerah berdasarkan Standar Akuntansi Pemerintah (SAP), harus memiliki karakteristik dasar sebagai berikut:

a. Relevan

b. Andal

c. Dapat dibandingkan

d. Dapat dipahami

\subsubsection{Tinjauan Umum Atas Audit}

1. Standar Auditing

Standar Auditing merupakan pedoman untuk membantu auditor dalam memenuhi tanggung jawab profesinya untuk melakukan audit atas laporan keuangan. Standar audit mencerminkan ukuran mutu pekerjaan audit laporan keuangan. Menurut standar audit referensi Standar Profesional Akuntan Publik (SPAP), terdiri atas sepuluh standar, dan terbagi dalam tiga kelompok yaitu (Arens, 2010:42):
a. Standar Umum
b.Standar Pekerjaan Lapangan
c. Standar Pelaporan

\subsubsection{Independensi}

Independen berarti pemeriksa tidak mudah dipengaruhi. Pemeriksa tidak dibenarkan memihak kepentingan siapapun. Pemeriksa berkewajiban untuk jujur tidak hanya kepada manajemen dan pemilik perusahaan, namun juga kepada kreditur dan pihak lain yang meletakkan kepercayaan atas pekerjaan akuntan publik.Setyaningrum (2010:34). Independensi berarti sikap mental yang bebas dari pengaruh, tidak dikendalikan oleh pihak lain, tidak tergantung pada orang lain. Independensi juga berarti adanya kejujuran dalam diri auditor dalam mempertimbangkan fakta dan adanya pertimbangan yang obyektif tidak memihak dalam diri auditor dalam merumuskan dan menyatakan pendapatnya (Mulyadi, 2002:26-27).29 Sawyer (2006:35) membagi 3 mengenai independensi, yaitu: independensi dalam verifikasi, independensi dalam program audit, dan independensi dalam pelaporan yang dapat diperuntukkan bagi akuntan public atau auditor eksternal, tetapi konsep yang sama dapat diterapkan untuk auditor internal dalam bersikap objektif. Independensi dalam hal ini adalah independensi dalam pelaporan dimana menurut Sawyer (2006:36) independensi dalam pelaporan menjadikan auditor internal: harus bebas dari perasaan untuk memodifikasi dampak dari fakta-fakta, harus bebas dari hambatan oleh pihak-pihak yang ingin meniadakan auditor dalam memberikan pertimbangan.

\subsubsection{Pengalaman Auditor}

Kusumastuti (2008:56) menyatakan bahwa pengalaman adalah keseluruhan perjalanan yang di petik oleh seseorang dari peristiwa-peristiwa yang di alami dalam perjalanan hidupnya. Pengalaman berdasarkan lama bekerja merupakan pengalaman auditor yang dihitung berdasarkan suatu waktu atau tahun. Sehingga auditor yang telah lama bekerja sebagai auditor dapat dikatakan berpengalaman. Karena semakin lama bekerja menjadi auditor, maka akan dapat menambah dan memperluas pengetahuan auditor dibidang akuntansi dan dibidang auditing. Pengalaman merupakan suatu proses pembelajaran dan pertambahan perkembangan potensi bertingkah laku baik dari pendidikan formal maupun non formal atau bisa diartikan sebagai suatu proses yang membawa seseorang kepada suatu pola tingkah laku yang lebih tinggi. Suatu pembelajaran juga mencakup perubahaan yang relatif tepat dari perilaku yang diakibatkan pengalaman, pemahaman dan praktek. (Asih,2006:12).

Sukriah, dkk (2009:4) menyimpulkan bahwa semakin banyak pengalaman kerja seorang auditor maka semakin meningkat kualitas hasil pemeriksaan yang dilakukan. Seseorang yang melakukan pekerjaan sesuai dengan pengetahuan yang dimilikinya akan memberikan hasil yang baik daripada mereka yang tidak memiliki pengetahuan yang cukup dalam menjalankan tugasnya. Kenyataan menunjukkan bahwa semakin lama seseorang bekerja maka, semakin banyak pengalaman yang dimiliki pekerja tersebut.Sebaliknya, semakin singkat masa kerja berarti semakin sedikit pengalaman yang diperolehnya. Pengalaman bekerja memiliki keahlian dan keterampilan kerja yang cukup namun sebaliknya, keterbatasan kerja mengakibatkan tingkat keterampilan dan keahlian yang dimiliki semakin rendah. Kebiasaan untuk melakukan tugas dan pekerjaan sejenis merupakan sarana positif untuk meningkatkan keahlian tenaga kerja. 


\subsubsection{Skeptisme Profesional Auditor}

Skeptisme profesional auditor merupakan sikap (attitude) auditor dalam melakukan penugasan audit dimana sikap ini mencakup pikiran yang selalu mempertanyakan dan melakukan evaluasi secara kritis terhadap bukti audit. Karena bukti audit dikumpulkan dan dinilai selama proses audit, maka skeptisme profesional harus digunakan selama proses audit, maka skeptisme profesional harus digunakan selama proses tersebut (IAI. 2001, SA seksi 230; AICPA, 2002, AU 230). Skeptisme professional sebagai kepribadian auditor mencakupi kehati-hatian, kewaspadaan, tidak langsung percaya saja, critical assessment (penilaian kritis), mempertanyakan validitas bukti, tingkat handal bukti, mewaspadai bukti kontradiktif, keaslian bukti, rekayasa bukti, mencurigai hal-hal mencurigakan, menilai hasil observasi yang tidak di-samarata-kan, melakukan evaluasi cermat dan membuat kesimpulan konservatif. Skeptisme merupakan manifestasi dan obyektivitas. Skeptisme tidak berarti bersikap sinis, terlalu banyak mengkritik atau melakukan penghinaan. Auditor yang memiliki skeptisme profesional yang memadai akan berhubungan dengan pertanyaan-pertanyaan berikut : (1) Apa yang perlu saya ketahui?, (2) Bagaimana caranya saya bisa mendapat informasi tersebut dengan baik?, (3) Apakah informasi yang saya peroleh masuk akal? Skeptisme profesional auditor akan mengarahkannya untuk menanyakan setiap isyarat yang menunjukkan kemungkinan terjadinya (Waluyo, 2008:24).

\subsubsection{Kompetensi}

Pernyataan standar umum pertama (SPKN dalam paragraf 02 dan 03) adalah : "Pemeriksa secara kolektif harus memiliki kecakapan professional yang memadai untuk melaksanakan tugas pemeriksaan". Dengan Pernyataan Standar Pemeriksaan ini semua organisasi pemeriksa bertanggung jawab untuk memastikan bahwa setiap pemeriksaan dilaksanakan oleh para pemeriksa yang secara kolektif memiliki pengetahuan, keahlian, dan pengalaman yang dibutuhkan untuk melaksanakan tugas tersebut. Oleh karena itu, organisasi pemeriksa harus memiliki prosedur rekrutmen, pengangkatan, pengembangan berkelanjutan, dan evaluasi atas pemeriksa untuk membantu organisasi pemeriksa dalam mempertahankan pemeriksa yang memiliki kompetensi yang memadai.

Kompetensi adalah keahlian professional yang dimiliki oleh auditor sebagai hasil dari pendidikan formal, ujian profesional maupun keikutsertaan dalam pelatihan seminar, symposium dan lain-lain (Suraida, 2005). Menurut Sri Lastanti (2005) mendefinisikan kompetensi sebagai keterampilan dari seorang ahli. Dimana ahli didefinisikan sebagai seorang yang memiliki tingkat keterampilan tertentu atau pengetahuan yang tinggi dalam subjek tertentu yang diperoleh dari pelatihan dan pengalaman. Sedangkan Saifuddin (2004) mendefinisikan bahwa seseorang yang berkompeten adalah orang yang dengan keterampilannya mengerjakan pekerjaan dengan mudah, cepat, intuitif dan sangan jarang atau tidak pernah membuat kesalahan.

\subsection{Pendeteksian Kecurangan}

Dalam Standar Auditing (SA) seksi 316 - Pertimbangan atas Kecurangan Dalam Audit Laporan Keuangan (PSA No. 70) menyebutkan ada dua tipe salah saji yang relevan dengan pertimbangan auditor tentang kecurangan dalam audit atas Laporan Keuangan:

a. Salah saji yang timbul dari kecurangan dalam pelaporan keuangan adalah salah saji atau penghilangan secara sengaja jumlah atau pengungkapan dalam laporan keuangan untuk mengelabuhi pemakai laporan keuangan. Kecurangan dalam laporan keuangan dapat menyangkut tindakan seperti: (a) manipulasi, pemalsuan, atau perubahan catatan akuntansi atau dokumen pendukungnya yang menjadi sumber data bagi penyajian laporan keuangan (b) representasi yang salah dalam atau penghilangan dari laporan keuangan peristiwa, transaksi, atau informasi signifikan (c) salah penerapan secara sengaja prinsip akuntansi yang berkaitan dengan jumlah, klasifikasi, cara penyajian atau pengungkapan.

b. Salah saji yang timbul dari perlakuan tidak semestinya terhadap aktiva (seringkali disebut dengan penyalahgunaan atau penggelapan) berkaitan dengan pencurian aktiva entitas yang berakibat laporan keuangan tidak disajikan sesuai dengan prinsip akuntansi yang berlaku umum di Indonesia.Perlakuan tidak semestinya terhadap aktiva entitas dapat dilakukan dengan berbagai cara termasuk penggelapan tanda terima barang/uang, pencurian aktiva, atau tindakan yang menyebabkan entitas membayar harga barang atau jasa yang tidak diterima oleh entitas. Perlakuan tidak semestinya terhadap aktiva dapat disertai dengan catatan atau dokumen palsu atau yangmenyesatkan dan dapat menyangkut satu atau lebih individu diantara manajemen, karyawan, atau pihak ketiga.

Deteksi kecurangan mencakup identifikasi indikator-indikator kecurangan (fraud indicators) yang memerlukan tindaklanjut auditor untuk melakukan investigasi. Ramaraya (2008:4) menyatakan bahwa pendeteksian kecurangan bukan merupakan tugas yang mudah dilaksanakan oleh auditor. Atas literatur yang tersedia, dapat dipetakan empat faktor yang teridentifikasi yang menjadikan pendeteksian kecurangan menjadi sulit dilakukan sehingga auditor gagal dalam usaha mendeteksi. Faktor-faktor penyebab tersebut adalah:

1.Karakteristik terjadinya kecurangan

2.Memahami Standar pengauditan mengenai pendeteksian kecurangan

3.Lingkungan pekerjaan audit yang mengurangi kualitas audit

4.Metode dan prosedur audit yang tidak efektif dalam pendeteksian kecurangan. 


\subsection{Aparat Pengawas Intern Pemerintah (APIP)}

Untuk menjamin agar penyelenggaraan pemerintahan berjalan sesuai dengan tujuan dan sasaran yang diharapkan, maka perlu adanya pengawasan. Pengawasan dilakukan oleh pihak-pihak yang berwenang, baik pengawasan oleh pihak eksternal maupun pihak internal. Pihak eksternal yang mengawasi penyelenggaraan pemerintahan adalah Badan Pemeriksa Keuangan Republik Indonesia (BPK-RI) sedangkan pihak internal yang melakukan pengawasan adalah Aparat Pengawasan Intern Pemerintah. (APIP).

Aparat pengawasan Intern Pemerintah (APIP) adalah Instansi Pemerintah yang mempunyai tugas pokok dan fungsi melakukan pengawasan, dan terdiri atas :

1. Badan Pengawasan Keuangan dan Pembangunan (BPKP) yang bertanggung jawab kepada Presiden;

2. Inspektorat Jenderal (Itjen)/Inspektorat Utama (Ittama)/Inspektorat yang bertanggung jawab kepada Menteri/Kepala Lembaga Pemerintah Non Departemen (LPND);

3. Inspektorat Pemerintah Propinsi yang bertanggung jawab kepada Gubernur, dan;

4. Inspektorat Pemerintah Kabupaten/Kota yang bertanggung jawab kepada Bupati/Walikota.

\subsection{Penelitian Terdahulu}

Penelitian Taufik (2008) tentang Pengaruh Pengalaman Kerja dan Pendidikan Profesional Auditor Internal terhadap Kemampuan Mendeteksi Fraud, yang berkesimpulan bahwa pengalaman kerja dan pendidikan profesional secara bersama-sama berpengaruh secara signifikan terhadap kemampuan mendeteksi fraud. Penelitian Noviyanti (2007) tentang skeptisme profesional auditor dalam mendeteksi kecurangan, yaitu meneliti faktor-faktor yang mempengaruhi skeptisme profesional auditor. Dengan kesimpulan bahwa jika auditor diberi penaksiran risiko kecurangan yang tinggi akan menunjukkan skeptisme profesional yang lebih tinggi dalam mendeteksi kecurangan, dan kepribadian mempengaruhi sikap skeptisme profesional auditor.

Penelitian lain yang dilakukan oleh Fitriany (2012), dalam penelitian yang berjudul Pengaruh Beban Kerja, Pengalaman Audit Dan Tipe Kepribadian Terhadap Skeptisme Profesional Dan Kemampuan Auditor Dalam Mendeteksi Kecurangan. Hasil penelitian menyatakan bahwa beban kerja berpengaruh negatif terhadap peningkatan kemampuan auditor dalam mendeteksi gejala-gejala kecurangan, sedangkan pengalaman audit dan skeptisme profesional terbukti berpengaruh positif terhadap peningkatan kemampuan auditor mendeteksi gejala-gejala kecurangan.Penelitian lain yang dilakukan oleh Matondang (2010), dalam penelitian menyatakan bahwa pengalaman, independensi dan keahlian professional berpengaruh terhadap pencegahan dan pendeteksian kecurangan.

\section{KERANGKA KONSEPTUAL}

\subsection{Kerangka Konseptual}

Berdasarkan Latar Belakang masalah, rumusan permasalahan, dan teori yang ada maka kerangka pemikiran dari penelitian ini adalah sebagai berikut :

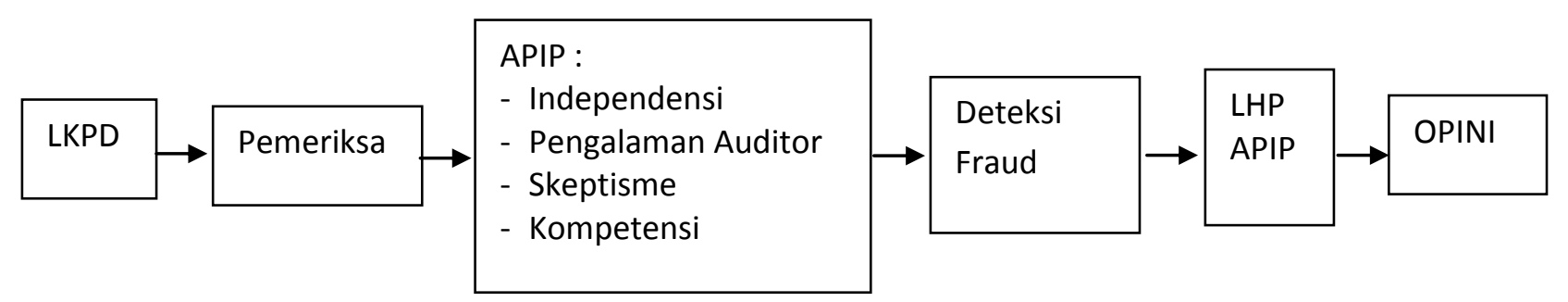

Gambar 3.1. Kerangka berpikir

1. Audit dilakukan oleh APIP Inspektorat sebagai instansi resmi pemerintah yang dibentuk dan ditugaskan untuk melakukan pengawasan terhadap pelaksanaan urusan pemerintahan daerah, pelaksanaan pembinaan atas penyelenggaraan pemerintahan daerah, dan urusan pemerintahan di daerah.

2. Dalam melaksanakan proses audit/pemeriksaan APIP selain diharapkan mematuhi peraturan perundangan yang berlaku juga dapat mendeteksi kecurangan-kecurangan yang terjadi.

3. Bagi APIP jika kecurangan tidak dapat dideteksi, kendala-kendala apakah yang dihadapi saat proses pemeriksaan berlangsung.

4. Upaya apa yang dapat dilakukan agar APIP dapat mendeteksi kecurangan yang dapat menunjang tingkat kewajaran laporan keuangan.

\subsection{Model Analisis}

Dalam Penelitian ini pendekatan yang dilakukan adalah melalui pendekatan kualitatif. Artinya data yang dikumpulkan bukan berupa angka-angka, melainkan data tersebut berasal dari naskah wawancara, pengamatan/observasi, dokumen pribadi, dan dokumen resmi lainnya. Sehingga yang menjadi tujuan dari penelitian kualitatif ini adalah ingin menggambarkan realita empirik dibalik fenomena secara mendalam, rinci dan tuntas. Oleh 
karena itu penggunaan pendekatan kualitatif dalam penelitian ini adalah dengan mencocokkan antara realita empiric dengan teori yang berlaku dengan menggunakan metode kualitatif. Metode kualitatif adalah metode penelitian yang digunakan untuk meneliti pada kondisi obyek yang alamiah, dimana peneliti adalah sebagai instrument kunci, teknik pengumpulan data dilakukan secara gabungan, analisis data bersifat induktif, dan hasil penelitian kualitatif lebih menekankan makna dari pada generalisasi.

\subsubsection{Metode Etnografi}

Dalam tradisi penelitian yang menggunakan pendekatan kualitatif, etnografi dikenal sebagai salah satu tradisi kualitatif. Istilah Etnografi berasal dari bahasa Yunani yaitu ethnos (bangsa) yang berarti orang atau folk. Etnografi secara harafiah dapat dipahami sebagai upaya penggambaran (mendeskripsikan) suatu budaya atau cara hidup orangorang dalam sebuah komunitas tertentu. Etnografi adalah uraian dan penafsiran suatu budaya atau system kelompok social. Peneliti menguji kelompok tersebut dan mempelajari pola perilaku, kebiasaan dan cara hidup. Etnografi adalah sebuah proses dan hasil dari sebuah penelitian. Sebagai sebuah proses, etnografi melibatkan pengamatan yang cukup panjang terhadap suatu kelompok, sehingga peneliti memahami betul bagaimana kehidupan keseharian subjek penelitian tersebut (participant observation, life history), yang kemudian diperdalam dengan indepth interview terhadap masing-masing individu dalam kelompok tersebut.

\section{METODE PENELITIAN}

\subsection{Jenis Penelitian yang digunakan}

Penelitian ini menggunakan pendekatan kualitatif, dengan metode etnografi. Studi etnografi merupakan salah satu dari lima tradisi kualitatif, yaitu biografi, fenomenologi, grounded theory, etnografi dan studi kasus. Penelitian ini disebut juga dengan penelitian alamiah (naturalistic inquiry), atau qualitative inquiry.

\subsection{Jenis Data}

Jenis Data ada 2 yaitu data primer dan data sekunder. Dalam penelitian ini digunakan 2 jenis data tersebut. Data primer adalah data yang dapat diperoleh langsung dari lapangan atau tempat penelitian. Sumber data utama dalam penelitian kualitatif ialah kata-kata dan tindakan. Kata-kata dan tindakan merupakan sumber data yang diperoleh dari lapangan dengan mengamati atau mewawancarai. Dalam penelitian ini penulis menggunakan data primer, data ini diperoleh dari hasil pengamatan langsung terhadap APIP Inspektorat. Pengamatan dilakukan terhadap tingkat kompetensi, kepatuhan terhadap aturan pemeriksaan, proses pemeriksaan di lapangan, sampai dengan penyusunan Laporan Hasil Pemeriksaan.

Data sekunder adalah data pelengkap untuk menunjang keabsahan data primer. Dalam penelitian ini data sekunder adalah Laporan Hasil Pemeriksaan, Peraturan-peraturan, dan data pendukung lainnya yang menurut penulis dapat memperkuat penemuan dan melengkapi informasi yang telah dikumpulkan melalui wawancara langsung.

\subsection{Sumber Data}

Sumber data dalam penelitian adalah wawancara mendalam terhadap responden, observasi langsung di lapangan, dan permintaan dokumen pendukung lainnya. Responden yang diwawancarai adalah pejabat Inspektorat Kota Manado yang dalam pelaksanaan pemeriksaan memiliki kapasitas sebagai penanggung jawab atau pengendali mutu.

\subsection{Instrumen Penelitian}

Instrumen penelitian ini adalah wawancara mendalam, observasi, dan dokumentasi. Dalam penelitian kualitatif, penulis adalah ujung tombak sebagai pengumpul data (instrumen). Penulis terjun secara langsung ke lapangan untuk mengumpulkan sejumlah informasi yang dibutuhkan.

\subsection{Lokasi dan Waktu Penelitian}

Lokasi penelitian adalah Kantor Inspektorat Kota Manado yang beralamat di Jalan Balai Kota No. 1 Tikala Ares, Manado. Waktu Penelitian adalah selama Tahun anggaran 2015 serta ditambahkan dengan pengamatan dari pengalaman yang diperoleh penulis selama menjadi APIP di Inspektorat Kota Manado.

\subsection{Prosedur Pengumpulan Data}

Metode yang digunakan untuk proses pengumpulan data dalam penelitian ini adalah dengan proses trianggulasi, yaitu :

\section{Wawancara}

Wawancara adalah percakapan dengan maksud tertentu. Percakapan itu dilakukan oleh kedua belah pihak, yaitu pewancara (interviewer) yang mengajukan pertanyaan dari yang diwawancarai (interviewee). Wawancara digunakan oleh peneliti untuk menggunakan menilai keadaan seseorang. Dalam wawancara tersebut biasa dilakukan secara individu maupun dalam bentuk kelompok, sehingga didapat data informatik yang orientik.

Metode Inteview adalah sebuah dialog atau Tanya jawab yang dilakukan dua orang atau lebih yaitu pewawancara dan terwawancara (nara sumber) dilakukan secara berhadap-hadapan. Dalam penelitian ini interview yang dilakukan adalah secara individu dan berhadap-hadapan dengan terwawancara.

2. Pengamatan/Observasi

Sebagai metode ilmiah observasi dapat diartikan sebagai pengamatan, meliputi pemusatan perhatian terhadap suatu obyek dengan menggunakan alat indra terutama mata terhadap kejadian yang berlangsung dan dapat 
dianalisa pada waktu kejadian itu terjadi. Metode ini dilakukan dengan cara pengamatan secara langsung dengan obyek yang diteliti. Sehingga peneliti mengamati langsung cara kerja, teknik pelaksanaan pemeriksaan sampai pada pelaporan hasil pemeriksaan. Sehingga dampak dari hasil pemeriksaan dapat diketahui peneliti apa yang menjadi sebab dan akibatnya.

3. Dokumentasi

Dokumentasi berasal dari kata dokumen, yang berarti barang tertulis, metode dokumentasi berarti cara pengumpulan data dengan mencatat data-data yang sudah ada. Teknik atau studi dokumentasi adalah cara pengumpulan data melalui peninggalan arsip-arsip dan termasuk juga buku-buku tentang pendapat, teori, dalildalil atau hukum-hukum dan lain-lain yang berhubungan dengan masalah penelitian. Dalam penelitian ini dokumentasi yang digunakan adalah berupa hasil rekaman wawancara terhadap responden dan peraturanperaturan yang mengatur.

\subsection{Cara Pengolahan dan Analisis Data}

Dalam suatu penelitian sangat diperlukan suatu analisis data yang berguna untuk memberikan jawaban terhadap permasalahan yang diteliti. Analisis data dalam penelitian ini menggunakan metode kualitatif. Penelitian dengan menggunakan metode kualitatif bertolak dari asumsi tentang realitas dan fenomena social yang bersifat unik dan komplek. Analisis data adalah proses mengatur urutan data, mengorganisasikan ke dalam suatu pola, kategori dan satuan uraian dasar. Sedangkan metode kualitatif merupakan prosedur penelitian yang menghasilkan data deskriptif berupa kata-kata tertulis atau lisan dari orang-orang dan perilaku yang dapat diamati.

\section{ANALISIS DAN PEMBAHASAN HASIL PENELITIAN}

\subsection{Gambaran Umum Objek Penelitian}

\subsubsection{Pemerintah Kota Manado}

Kota Manado yang berdiri pada Tanggal 14 Juli 1623, merupakan momentum yang mengemas tiga peristiwa bersejarah sekaligus yaitu tanggal 14 yang diambil dari peristiwa heroic yaitu peristiwa merah putih 14 Februari 1946 , dimana putera daerah ini bangkit dan menentang penjajah Belanda untuk mempertahankan kemerdekaan Indonesia. Kemudian bulan Juli yang diambil dari unsur yuridis yaitu bulan Juli 1919, yaitu munculnya Besluit Gubernur Jenderal tentang penetapan Gewest Manado sebagai Staatgemeente dikeluarkan, dan tahun 1623 yang diambil dari unsure historis yaitu tahun dimana Kota Manado dikenal dan digunakan dalam surat-surat resmi. Berdasarkan ketiga peristiwa penting tersebut, maka tanggal 14 Juli 1989 Kota Manado merayakan HUT-nya yang ke-367. Dan sejak itu hingga sekarang tanggal tersebut terus digunakan oleh masyarakat Manado sebagai hari peringatan ulang tahun Kota Manado.

VISI Kota Manado 2011-2015 : "Manado Kota Model Ekowisata" (Manado Model City for Ecotourism). Visi Pembangunan Daerah Kota Manado ini diharapkan akan mewujudkan harapan dan amanat masyarakat Kota Manado dengan tetap mengacu pada pencapaian tujuan nasional sebagaimana diamanatkan dalam pembukaan UUD 1945, serta selaras dengan RPJM Nasional 2010-2014, RPJMD Provinsi Sulawesi Utara 2010-2015 serta RPJPD Kota Manado 2005-2025. Visi pembangunan daerah Kota Manado tersebut harus jelas mudah dipahami oleh seluruh masyarakat dan dapat dicapai serta merupakan pencapaian satu tahapan dalam mewujudkan visi jangka panjang Kota Manado.

MISI Kota Manado 2011-2015 : "Menjadikan Manado sebagai kota yang Menyenangkan“ (To Make Manado a city of happiness). Misi merupakan komitmen untuk melaksanakan agenda-agenda utama yang menjadi penentu keberhasilan pencapaian visi pembangunan. Secara substansial misi pembangunan jangka menengah tahun 2011-2015 ini merupakan kelanjutan dari misi pembangunan jangka menengah sebelumnya yaitu Manado kota yang menyenangkan dimana setiap orang dapat mewujudkan potensi dan impiannya.

\subsubsection{Inspektorat Kota Manado}

Susunan Organisasi Inspektorat Kota Manado berdasarkan Peraturan Menteri Dalam Negeri Nomor : 64 Tahun 2007 tentang Pedoman Teknis Organisasi dan Tata Kerja Inspektorat Provinsi dan Kabupaten/Kota dengan tetap mengacu pada Peraturan Pemerintah Republik Indonesia Nomor : 41 Tahun 2007 tentang Organisasi Perangkat Daerah.Dasar hukum pembentukan Inspektorat Kota Manado adalah Peraturan DaerahKota Manado Nomor 5 tahun 2008. Sedangkan rincian tugas pokok dan fungsi diatur dengan Peraturan Walikota Manado Nomor : 31 tahun 2008 tentang Rincian Tugas dan Fungsi Inspektorat Kota Manado, sebagai pedoman bagi Inspektorat Kota Manado dalam menjalankan tugas pokok dan fungsinya. Adapun susunan organisasi Inspektorat Kota Manado adalah sebagai berikut :

1. Inspektur

Mempunyai tugas pokok menyelenggarakan urusan bidang pengawasan berdasarkan asas desentralisasi, dekonsentrasi dan tugas pembantuan.

2. Sekretaris

Mempunyai tugas menyiapkan bahan koordinasi pengawasan dan memberikan pelayanan administrasi dan fungsional kepada semua unsure di lingkungan Inspektorat kota Manado. Sekretaris membawahi :

a. Subbagian Program, Keuangan, Pelaporan;

bertugas menyiapkan bahan penyusunan dan pengendalian rencana/program kerja pengawasan, dokumentasi dan pengolahan data pengawasan. Serta bertugas menyiapkan bahan penyusunan, menghimpun, mengelola dan menyimpan laporan hasil pengawasan aparat pengawas fungsional, dan melakukan administrasi pengaduan masyarakat serta menyusun laporan kegiatan pengawasan. 
b. Subbagian Umum dan Perlengkapan

bertugas melakukan urusan penatausahaan surat menyurat dan urusan rumah tangga.

c. Subbagian Kepegawaian.

bertugas melakukan urusan kepegawaian.

3. Inspektur Pembantu Wilayah I, membawahi :

a. Seksi Pengawas Pemerintah Bidang Pembangunan;

b. Seksi Pengawas Pemerintah Bidang Pemerintahan;

c. Seksi Pengawas Pemerintah Bidang Kemasyarakatan.

4. Inspektur Pembantu Wilayah II, membawahi :

a. Seksi Pengawas Pemerintah Bidang Pembangunan;

b. Seksi Pengawas Pemerintah Bidang Pemerintahan;

c. Seksi Pengawas Pemerintah Bidang Kemasyarakatan.

5. Inspektur Pembantu Wilayah III, membawahi :

a. Seksi Pengawas Pemerintah Bidang Pembangunan;

b. Seksi Pengawas Pemerintah Bidang Pemerintahan;

c. Seksi Pengawas Pemerintah Bidang Kemasyarakatan.

Inspektur Pembantu mempunyai tugas melaksanakan pengawasan terhadap urusan pemerintahan daerah dan kasus pengaduan.

6. Kelompok Jabatan Fungsional.

Kelompok jabatan fungsional terdiri atas pejabat fungsional auditor dan jabatan fungsional lainnya yang mempunyai tugas melakukan kegiatan sesuai dengan bidang tenaga fungsional masing-masing, serta sesuai dengan ketentuan peraturan perundang-undangan.

\subsection{Hasil Penelitian}

\subsubsection{Fungsi Sistem Pengendalian Intern Pemerintah}

Sistem Pengendalian Intern adalah proses yang integral pada tindakan dan kegiatan yang dilakukan secara terus menerus oleh pimpinan dan seluruh pegawai untuk memberikan keyakinan memadai atas tercapainya tujuan organisasi melalui kegiatan yang efektif dan efisien, keandalan pelaporan keuangan, pengamanan aset negara, dan ketaatan terhadap peraturan perundang-undangan.

Sistem Pengendalian Intern Pemerintah, yang selanjutnya disingkat SPIP, adalah Sistem Pengendalian Intern yang diselenggarakan secara menyeluruh di lingkungan pemerintah pusat dan pemerintah daerah. Pengawasan Intern adalah seluruh proses kegiatan audit, reviu, evaluasi, pemantauan, dan kegiatan pengawasan lain terhadap penyelenggaraan tugas dan fungsi organisasi dalam rangka memberikan keyakinan yang memadai bahwa kegiatan telah dilaksanakan sesuai dengan tolok ukur yang telah ditetapkan secara efektif dan efisien untuk kepentingan pimpinan dalam mewujudkan tata kepemerintahan yang baik.

Lembaga-lembaga yang berwenang melalukakn fungsi sistem pengendalian internal di Indonesia disebut Aparat Pengawasan Intern Pemerintah (APIP), antara lain:

a. BPKP;

b. Inspektorat Jenderal atau nama lain yang secara fungsional melaksanakan pengawasan intern;

c. Inspektorat Provinsi; dan

d. Inspektorat Kabupaten/Kota

a. Badan Pengawasan Keuangan dan Pembangunan, yang selanjutnya disingkat BPKP, adalah aparat pengawasan intern pemerintah yang bertanggung jawab langsung kepada Presiden. BPKP melakukan pengawasan intern terhadap akuntabilitas keuangan negara atas kegiatan tertentu yang meliputi:

a. kegiatan yang bersifat lintas sektoral;

b. kegiatan kebendaharaan umum negara berdasarkan penetapan oleh Menteri Keuangan selaku Bendahara Umum Negara; dan

c. kegiatan lain berdasarkan penugasan dari Presiden.

b. Inspektorat Jenderal atau nama lain yang secara fungsional melaksanakan pengawasan intern adalah aparat pengawasan intern pemerintah yang bertanggung jawab langsung kepada menteri/pimpinan lembaga.

Inspektorat Jenderal atau nama lain yang secara fungsional melaksanakan pengawasan intern melakukan pengawasan terhadap seluruh kegiatan dalam rangka penyelenggaraan tugas dan fungsi kementerian negara/lembaga yang didanai dengan Anggaran Pendapatan dan Belanja Negara.

c. Inspektorat Provinsi adalah aparat pengawasan intern pemerintah yang bertanggung jawab langsung kepada gubernur. Inspektorat Provinsi melakukan pengawasan terhadap seluruh kegiatan dalam rangka penyelenggaraan tugas dan fungsi satuan kerja perangkat daerah provinsi yang didanai dengan Anggaran Pendapatan dan Belanja Daerah provinsi.

d. Inspektorat Kabupaten/Kota adalah aparat pengawasan intern pemerintah yang bertanggungjawab keepada bupati/Walikota. 
Inspektorat Kabupaten/Kota melakukan pengawasan terhadap seluruh kegiatan dalam rangka penyelenggaraan tugas dan fungsi satuan kerja perangkat daerah kabupaten/kota yang didanai dengan Anggaran Pendapatan dan Belanja Daerah kabupaten/kota. Aparat pengawasan intern pemerintah melakukan pengawasan intern melalui:

a. audit;

b. reviu;

c. evaluasi;

d. pemantauan; dan

e. kegiatan pengawasan lainnya

\subsubsection{Reviu atas Laporan Keuangan}

Peraturan Pemerintah Nomor 8 tahun 2006 mewajibkan laporan keuangan direviu oleh APIP sebelum diserahkan kepada BPK untuk diaudit. Reviu atas laporan keuangan departemen dilakukan oleh Inspektorat Jenderal dan reviu laporan keuangan Pemerintah daerah (LKPD) dilakukan oleh Inspektorat Provinsi dan Inspektorat Kabupaten/Kota.

\section{Pengertian Reviu atas Laporan Keuangan}

Menurut pasal 33 Peraturan Pemerintah Nomor 8 Tahun 2006: Reviu yang dilakukan dimaksudkan untuk memberikan keyakinan terbatas atas laporan keuangan dalam rangka pernyataan tanggung jawab (statement of responsibility) atas laporan keuangan tersebut. Pernyataan tanggung jawab memuat pernyataan bahwa laporan keuangan telah disusun berdasarkan sistem pengendalian intern yang memadai dan sesuai dengan standar akuntansi Pemerintahan (SAP). Reviu yang akan dilakukan berdasarkan PP tersebut harus meliputi reviu atas sistem pengendalian intern dan kesesuaian dengan SAP. Namun demikian, sistem pengendalian intern yang direviu dibatasi pada pengendalian yang berkaitan dengan penyusunan laporan keuangan. Reviu dimaksudkan untuk memberikan keyakinan akurasi, keandalan, dan keabsahan informasi yang disajikan dalam laporan keuangan sebelum disampaikan oleh pejabat pengelola keuangan kepada menteri/pimpinan lembaga dan kepala daerah. Jadi sebelum menteri/pimpinan lembaga dan kepala daerah menandatangani surat pernyataan tanggung jawab maka APIP harus melakukan reviu terlebih dahulu.

Pengertian reviu atas laporan keuangan menurut Standar Profesional Akuntan Publik (SPAP). Pelaksanaan prosedur permintaan keterangan dan analisis yang menghasilkan dasar memadai bagi akuntan untuk memberikan keyakinan terbatas bahwa tidak ada modifikasi material yang harus dilakukan atas laporan keuangan agar laporan keuangan tersebut sesuai dengan prinsip akuntansi berlaku umum di Indonesia atau sesuai dengan basis akuntansi komprehensif yang lain. Reviu tidak mencakup suatu pemahaman atas pengendalian intern, pengujian atas catatan akuntansi, dan pengujian atas respon terhadap permintaan keterangan dengan cara pemerolehan bahan bukti dan prosedur tertentu lainnya yang biasanya dilaksanakan dalam suatu audit.

Menurut Peraturan Direktur Jenderal Perbendaharaan Nomor PER-44/PB/2006 Tentang Pedoman Pelaksanaan Reviu Laporan Keuangan Kementerian Negara/Lembaga: Prosedur penelusuran angka-angka dalam laporan keuangan, permintaan keterangan, dan analitik yang harus menjadi dasar memadai bagi Aparat Pengawasan Intern Pemerintah (APIP) untuk memberi keyakinan terbatas bahwa tidak ada modifikasi material yang harus dilakukan atas laporan keuangan agar laporan keuangan tersebut sesuai dengan Standar Akuntansi Pemerintahan.

\section{Konsep Reviu atas Laporan Keuangan}

Berdasarkan beberapa pengertian di atas konsep dasar reviu adalah sebagai berikut:

a. Reviu dilaksanakan secara paralel dengan penyusunan laporan keuangan Pemerintah. Reviu paralel dimaksudkan untuk memperoleh informasi tepat waktu agar koreksi dapat dilakukan segera.

b. Reviu tertuju pada hal-hal penting yang mempengaruhi laporan keuangan, namun tidak memberikan keyakinan akan semua hal penting yang akan terungkap melalui suatu audit. Reviu memberikan keyakinan bagi APIP bahwa tidak ada modifikasi (koreksi/penyesuaian) material yang harus dilakukan atas laporan keuangan agar laporan keuangan yang direviu sesuai dengan SAP, baik segi pengakuan, penilaian, pengungkapan dan sebagainya.

c. Reviu tidak memberikan dasar untuk menyatakan suatu pendapat (opini) seperti halnya dalam audit, meskipun reviu mencakup suatu pemahaman atas pengendalian intern secara terbatas.

d. Tidak dilakukan pengujian terhadap kebenaran substansi dokumen sumber seperti perjanjian kontrak pengadaan barang dan jasa, bukti pembayaran/kuitansi, dan berita acara fisik atas pengadaan barang dan jasa.

e. Dalam melakukan reviu atas laporan keuangan, APIP harus memahami secara garis besar sifat transaksi entitas, sistem dan prosedur akuntansi, bentuk catatan akuntansi dan basis akuntansi yang digunakan untuk menyajikan laporan keuangan.

Kompetensi umum yang perlu dimiliki oleh pelaksana reviu adalah:

a. Pemahaman mengenai akuntansi, khususnya akuntansi sektor publik/Pemerintahan, termasuk pemahaman terhadap Standar Akuntansi Pemerintahan,

b. Pemahaman mengenai sistem pengendalian intern. Dalam pelaksanannya, reviu berbeda dengan audit yaitu :

a. Reviu tidak menguji bukti, hanya sampai alur dari jurnal-buku besar-laporan keuangan. 
b. Reviu atas sistem pengendalian intern terbatas pada pengendalian akuntansi, berupa proses akuntansi pendapatan, pengeluaran, aset, dan non-kas.

Hasil reviu ini kemudian disampaikan kepada menteri/pimpinan lembaga dan kepala daerah untuk dijadikan dasar menerbitkan pernyataan tanggung jawab menteri/pimpinan lembaga dan kepala daerah (statement of responsibility). Pernyataan tersebut antara lain menyatakan bahwa "Laporan Keuangan telah disusun dengan sistem pengendalian intern yang memadai dan sesuai dengan Standar Akuntansi Pemerintahan". Selanjutnya, jika dalam audit oleh BPK ditemukan salah saji dan diperlukan koreksi-koreksi, APIP sepatutnya mendampingi pejabat pengelola keuangan dalam proses exit meeting dan menyusun laporan keuangan yang telah diaudit sesuai koreksi dari audit eksternal (BPK).

\subsection{Pembahasan Hasil Penelitian}

\subsubsection{Independensi dan Obyektifitas}

Inpektorat Kota Manado berada di bawah dan bertanggung jawab kepada Walikota Manado menyebabkan terjadinya gangguan terhadap independensi auditor. Pemeriksaan yang dilakukan yang dilakukan terhadap kinerja dan akuntabilitas kepala SKPD, serta sering diperhadapkan dengan obyek pemeriksaan yang memiliki hubungan kekerabatan dengan auditor menyebabkan hasil audit yang tidak optimal. Akan tetapi adanya komitmen dari Walikota beserta jajarannya untuk menciptakan clean government dan good governance, maka para auditor dapat bekerja dengan optimal.

Seperti yang diungkapkan para pemeriksa :

Pemeriksa 1 menjawab pada umumnya seluruh APIP memang harus berintegritas dengan salah satu pembuktiannya harus jujur, karena hanya dengan integritas itu dapat membangun kepercayaan dan menghasilkan keputusan serta judgement yang andal. Dan ini secara otomatis ada dampak terhadap kualitas kerja kita.

Pemeriksa 2 mengatakan seperti banyak diketahui oleh masyarakat luas, bahwa Inspektorat merupakan kantor yang mengawasi jalannya aktivitas dalam pemerintahan untuk mengatasi kecurangan, termasuk didalamnya juga mendeteksi. Kepercayaan masyarakat itulah yang harus kita pegang. Dengan cara harus berpegang pada norma, etika dan aturan yang berlaku dalam melakukan pemeriksaan.

Dengan adanya kepercayaan masyarakat itulah, sikap jujur dan tidak menyimpang menjadi karakter yang sangat penting sekalipun para auditornya memilliki kecakapan dalam bekerja. Nilai kejujuran mempunyai posisi sentral. Kepandaian yang tidak bersumber atau tidak disertai kejujuran, tidak akan menopang pemeliharaan "induk kekayaan" Negara dan rakyat.

Pemeriksa 3 menjawab siapapun yang melakukan atau yang tersangka melakukan kecurangan, apakah dia adalah staf atau pihak atasan, ya harus obyektif. Tetap kita harus melakukan pemeriksaan, kita tidak takut, karena inilah yang menjadi tugas kita. Siapa yang melakukan, itulah yang harus menerima akibatnya.

Sekretaris Inspektorat menambahkan : di inspektorat, keadilan adalah pokok. Oleh karenanya itu, kita tidak melihat subyek yang diperiksa, dengan kata lain harus bersikap adil.

Untuk menjadi seorang auditor pemerintah tidaklah mudah. Tidak hanya mempunyai pendidikan formal ataupun latar belakang edukasi yang tinggi, tetapi harus melewati serangkaian pelatihan untuk melatih kompetensi. Oleh karena itu, seorang auditor yang handal untuk mendeteksi kecurangan harus memang memiliki skill yang luar biasa, cermat dan akurat dalam pekerjaannya. Terkadang pula mereka memiliki insting yang kuat yang terbentuk dari pengalaman dan skill itu sendiri yang dimilikinya.

Berikut petikan hasil wawancara seorang auditor yang mengungkapan syarat untuk menjadi seorang pemeriksa di Inspektorat :

Syarat dasar untuk menjadi seorang auditor yaitu persyaratan formalnya pendidikan minimal s1, telah menjadi PNS dengan masa kerja sekurang-kurangnya dua tahun. Dan tidak ada batasan bagi lulusan semua jurusan kecuali fungsional dokter dan guru, tapi yang berkaitan dengan lingkup pengawasan di pemerintahan itu dimungkinkan. Selanjutnya yang paling penting yaitu harus mengikuti diklat auditor yang diadakan oleh BPKP dan melulusi diklat tersebut. Sebab tidak jarang pula calon auditor yang gugur karena prosesnya yang terbilang sangat rumit, obyektif dan benar-benar melatih kompetensi calon auditor, termasuk ujian akhirnya untuk memperoleh sertifikat auditor. Oleh sebab itu, untuk menjadi auditor itu bukan hal yang mudah. Hal demikian adalah semata-mata untuk kepentingan auditor dan seluruh pemerintahan Kota Manado.

\subsubsection{Pendeteksian Kecurangan}

Pada dasarnya, audit Internal pemerintah merupakan pendamping pemerintah dalam penyelenggaraan daerah baik dari segi keuangan ataupun non-keuangan. Audit Internal menentukan apakah kebijakan dan prosedur pemerintah telah diikuti dan dijalankan di seluruh lapisan badan ataupun instansi pemerintahan. Sebab, erat kaitannya ketidaksesuaian kebijakan dan prosedur pemerintah yang telah dibuat dengan pelanggaran ataupun tindakan penyimpangan. Sebagaimana yang diketahui, tindakan fraud bermuara dari adanya tindakan pelanggaran. Oleh karena itu, pihak audit internal sebagai benteng kedua dalam menjalankan pemerintahan diharapkan berupaya mampu menghadapi berbagai persoalan kecurangan yang mana pelaksana pemeriksanya dibekali ilmu dan pengetahuan yang dimilkinya sehingga pelaksanaan audit dapat berjalan lancer dan tepat sasaran. Dengan demikian, audit internal 
diharapkan mampu mendeteksi terjadinya kecurangan dan dapat memberikan saran-saran yang bermanfaat kepada SKPD dan Kecamatan/Kelurahan untuk mengatasi kecurangan-kecurangan.

Dalam mendeteksi kecurangan, Inspektorat Kota Manado mengenali bentuk-bentuk dan cara seseorang melakukan tindakan kecurangan serta bagaimana menyusun sistem internal auditor yang baik. Hal ini memudahkan auditor dalam mendeteksi dan mencegah kecurangan-kecurangan. Kecurangan yang sering terjadi pada SKPD yaitu pembuatan SPPD (Surat Perintah Perjalanan Dinas) fiktif, mark-up harga pada pembelian barang, pengadaan barang dan jasa yang tidak sesuai dengan jumlah barang atau volume pekerjaan, tidak disiplinnya oknum PNS. Berdasarkan temuan tersebut dapat disimpulkan bahwa Inspektorat Kota Manado mampu memberikan kontribusi yang berarti dalam mendeteksi dan mengungkap kasus fraud yang berpengaruh terhadap kewajaran Laporan Keuangan. Kemudian kasus kecurangan kecurangan yang telah terdeteksi tersebut wajib ditindaklanjuti agar pada pemeriksaan tahun selanjutnya tidak terjadi lagi pelanggaran yang sama. Dengan begitu kasus kecurangan dapat diminimalisir.

Sedangkan deteksi kecurangan dilakukan yaitu dengan upaya menganalisis gejala-gejala kecurangan. Inspektorat selaku audit internal Kota Manado mendeteksi kecurangan dengan melihat indikasi-indikasi kemungkinan terjadinya kecurangan. Sebab kecurangan itu tidak mudah untuk dideteksi. Seperti dikemukakan oleh pemeriksa 3 :

Dalam mendeteksi kecurangan, pada saat kita memeriksa akan tampak dengan sendirinya gejala-gejala yang timbul. Salah satunya yang paling utama yaitu tidak adanya dokumen-dokumen serta tidak kooperatifnya

SKPD ataupun sebaliknya dimana SKPD yang overkooperatif. Selain itu, adanya hasil kegiatan yang tidak sesuai dengan perencanaan. Karena semakin mencurigakan, semakin kita juga mencari karena kita harus skeptis. Intinya, kita memang memiliki insting yang kuat.

Pemeriksa 2 juga mengatakan :

Tampaknya gejala kecurangan dalam pemeriksaan membuat kita semakin menginvestigasi gejala tersebut. Karena gejala itu bisa dianalisis melalui kelengkapan bukti dokumen pertanggungjawaban dari SKPD enggan memberikan keterangan lengkap seolah-olah menyembunyikan sesuatu.

Dengan demikian, kecurangan itu dapat terdeteksi lebih awal dengan adanya gejala-gejala yang menunjukkan sebuah ketidakwajaran seperti terdapatnya dokumen-dokumen yang mecurigakan, tidak kooperatifnya atau overkooperatif SKPD. Tentu saja penemuan ini tidaklah mudah, oleh karena auditor inspektorat memiliki skill/kemampuan yang baik, serta memiliki rasa curiga yang besar sehingga meningkatkan rasa ingin tahunya apakah terjadi kecurangan atau tidak.

Dalam institusi, keberhasilan Inspektorat Kota Manado dalam melakukan audit dapat dilihat dari upaya tindak lanjut oleh bagian pelaporan Inspektorat Kota Manado. Seperti hasil wawancara sebelumnya dikatakan bahwa efektifnya proses pemeriksaan apabila rekomendasi temuan dari hasil pemeriksaan oleh auditor tertindaklanjuti. Sesuai yang diungkapkan oleh pemeriksa 3 :

Untuk melihat efektifnya hasil audit bisa dilihat dari evaluasinya. Dalam artian adanya tindak lanjut dari temuan, apakah saran dari temuan sudah tertindaklanjuti atau tidak, kemudian memastikan apakah perbuatan penyimpangan kecurangan tidak berulang lagi di pemeriksaan selanjutnya.

Pemeriksa 2 juga menambahkan :

Yaitu dengan TL (tindak lanjut) yaitu dengan merekapitulasi semua temuan yang ada pada SKPD. Jika telah ditindaklanjuti, proses auditnya boleh dikatakan efektif. Sebaliknya jika persentase belum ditindaklanjutinya tinggi, maka boleh dikatakan bahwa audit belum efektif terlaksana.

Upaya tindak lanjut merupakan upsya untuk memastikan seluruh rekomendasi temuan oleh auditor telah dilaksanakan atau sesuai dengan sasaran rekomendasi ataupun pemberian sanksi sesuai tingkat kesalahan/penyimpangan yang telah dilakukan. Dengan begitu, upaya pendeteksian boleh dikatakan berhasil.

Sedangkan jika dilihat dari sudut luar institusi, Inspektorat Kota Manado telah menunjukkan kinerja yang baik sebagai lembaga APIP (Aparat Pengawas Internal Pemerintah). Hal ini dibuktikan dengan prestasi yang dicapai oleh Inspektorat Kota Manado. Seperti diungkapkan oleh Sekretaris Inspektorat Kota Manado :

Kota Manado mengalami peningkatan dalam memperoleh opini dari hasil pemeriksaan BPK, pada tahun 2012 WDP, tahun 2013 WDP dan pada tahun 2014 WTP. Selain itu juga menurunnya pula kasus-kasus kecurangan dalam dua tahun terakhir.

\section{KESIMPULAN DAN SARAN}

6.1. Kesimpulan

Dalam penelitian ini bertujuan untuk menganalisis fungsi Aparat Pengawas Internal Pemerintah (APIP) / Internal Auditor dalam menunjang tingkat kewajaran Laporan Keuangan. Berdasarkan data yang telah dikumpulkan dan dibandingkan dengan teori, maka dapat diambil kesimpulan sebagai berikut :

1. Fungsi APIP yang berjalan dengan baik dapat mencegah kecurangan, menghasilkan keluaran yang berharga untuk menjadi masukan bagi pihak auditor eksternal, eksekutif dan legislatif dalam memperbaiki pengelolaan dan pertanggungjawaban keuangan daerah pada waktu yang akan datang. BPK dapat memanfaatkan hasil pengawasan APIP terutama dari hasil reviu atas laporan keuangan pemerintah, mendukung manajemen pemerintah daerah dalam pelaksanaan rekomendasi BPK dan perbaikan sistem pengendalian Internal. APIP yang profesional dan independen mendorong peningkatan transparansi dan akuntabilitas pengelolaan keuangan yang dapat meningkatkan kewajaran laporan keuangan. 
2. Kecurangan terjadi umumnya disebabkan oleh lemahnya pengendalian internal dalam SKPD yang mendukung adanya kesempatan(opportunity), lalu tekanan (pressure) dan rasionalisasi (attitude). Lemahnya pengendalian internal di SKPD merupakan celah terjadinya fraud, akan tetapi kokohnya pengendalian internal dalam SKPD belum menjamin juga untuk tidak terjadi fraud, namun para pemeriksa di Inspektorat Kota Manado sangant maksimal bekerja dengan bekal kompetensi, skeptis, pengalaman serta kemahiran jabatannya sehingga dapat mendeteksi dan mengungkap terjadinya fraud melalui pemberian rekomendasi SKPD/manajemen.

3. Inspektorat Kota Manado melalui aparat pengawasnya menjalankan fungsi mendeteksi kecurangan dengan menganalisis dokumen-dokumen audit yang relevan, kompeten, cukup dan material. Sedangkan gejalagejala yang terjadinya kecurangan yaitu dapat dilihat dari tidak kooperatifnya pihak SKPD pada saat pemeriksaan.

4. Inspektorat Kota Manado sangat berperan dalam mendeteksi dan mencegah kecurangan. Hal ini dapat dilihat dari menurunnya kasus-kasus kecurangan di Pemerintahan Kota Manado dan yang tidak kalah pentingnya Pemerintah Kota Manado telah memperoleh status WTP (Wajar Tanpa Pengecualian) pada Saran periode 2014, meskipun pada periode sebelumnya masih ada status WDP (Wajar Dengan Pengecualian).

Inspektorat selaku aparat pengawas intern pemerintah daerah hendaknya melakukan pembinaan penyelenggaraan SPIP di setiap satuan kerja yang meliputi : sosialisasi SPIP, bimbingan teknis dan pengontrolan SPI di setiap satuan kerja secara periodik agar dapat meminimalisir kecurangan yang terjadi akibat lemahnya SPI dapat dideteksi secara dini, sehingga bisa dilakukan evaluasi dan perbaikan yang berdampak pada hasil audit dari pihak eksternal.

\section{DAFTAR PUSTAKA}

American Institute of Certified Public Accountants (AICPA). (1978). The Commission on Auditors Responsibilities: Report, Conclusions, and Recomemendation. New York: AICPA.

Amrizal, (2004)."Pencegahan dan Pendeteksian Kecurangan oleh Internal Auditor". Jakarta: Direktorat Investigasi BUMN dan BUMD Deputi Bidang Investigasi.

Arens A., Randal J. Elder, dan Mark S. Beasley, (2006). Auditing dan Jasa Assurance : Pendekatan Integrasi (Alih Bahasa: Herman Wibowo), Jilid 1,Edisi Keduabelas, Penerbit Erlangga, Jakarta.

Arens, A. \& Loebbecke, J.K. (2003). Auditing Pendekatan Terpadu buku 1 (edisi 8). (Alih bahasa, Jusuf, A. A.) Jakarta: Penerbit Salemba Empat.

Asih, Dwi Annaning Tyas. (2006). "Pengaruh Pengalaman Terhadap Peningkatan Keahlian Auditor Dalam Bidang Auditing”. Universitas Islam Indonesia, Yogyakarta.

Boynton,WilliamC.,JohnsonRaymonddanKell,WalterG.(2003). “ModernAuditing”. Seven Edition. New York: Juhn Willey and Sons Inc.

Dian, Indri Purnamasari, (2005)."Pengaruh Pengalaman Kerja Terhadap Hubungan Partisipasi dengan Efektifitas Sistem Informasi”, Jurnal Riset Akuntansi Keuangan, Jakarta.

Effendy, (2010). "Pengaruh Kompetensi, Independensi dan Motivasi terhadap Kualitas Audit Aparat Inspektorat dalam Pengawasan Keuangan Daerah”, Tesis Universitas Diponegoro Semarang.

Fahmi, Irham,(2008). “Analisis Kredit dan Fraud: Pendekatan Kualitatif dan Kuantitatif”. Alumni, Bandung,.

Ferdian, Riki dan Na'im, Ainun, (2006). "Pengaruh Problem-Based Learning(PBL) pada Pengetahuan tentang Kekeliruan dan Kecurangan (errors and irregularities)”. Simposium Nasional Akuntansi 9. Padang,.

Fitriany, Hafifah Nasution,(2012)."Pengaruh Beban Kerja, Pengalaman Audit Dan Tipe Kepribadian Terhadap Skeptisme Profesional Dan Kemampuan Auditor Dalam Mendeteksi Kecurangan",Universitas Indonesia, Jakarta.

Halim, Abdul, (2008).“Auditing: Dasar-Dasar Audit Laporan Keuangan”, Edisi Keempat. UPPAMP YKPN, Yogyakarta.

Herliansyah, Yudhi dan Ilyas, Meifida, (2006). "Pengaruh Pengalaman Auditor terhadapPenggunaan Bukti tidak Relevan dalam Auditor Judgment”. Simposium Nasional Akuntansi 9. Padang.

Herman, Edy, (2009). "Pengaruh Pengalaman dan Skeptisme Profesional Auditor Terhadap Pendeteksian Kecurangan”, Universitas Islam Negeri, Jakarta.

Hutasuhut, Ririn. (2012). Pentingnya Audit Internal Dalam Mendeteksi Kecurangan Pada Inspektorat Pemerintahan Provinsi Sumatera Utara. Universitas Sumatera Utara.

Ida, Suraida. (2005). "Pengaruh Etika, Kompetensi, Pengalaman Audit dan Risiko Audit terhadap Skeptisisme Profesional Auditor dan Ketepatan Pemberian Opini Akuntan Publik”. Sosiohumaniora, Vol. 7 No. 3, November 2005: 186-202 